\title{
Rappresentazione dell'intangibile, cultura beduina e tecnologie per connettere
}

\author{
Giuseppe Amoruso \\ Sara Conte \\ Polina Mironenko
}

Abstract

Come rivelare con il disegno il concetto primitivo dell'abitare radicato nelle origini dell'umanità? Quali sono i codici delle popolazioni nomadiche che caratterizzano l'identità giordana? La ricerca sulla rappresentazione del patrimonio intangibile vuole connettere le espressioni ed i fatti culturali da secoli radicati nella cultura beduina come tradizione economica e sociale di adattamento all'habitat medio-orientale. L'occasione nasce da un progetto di cooperazione internazionale rivolto alla valorizzazione delle collezioni museali dei musei del Folklore e delle Tradizioni Popolari presso il Teatro Romano di Amman.

La strategia di allestimento museale prevede la trasformazione degli spazi in luoghi della conoscenza e dell'esperienza anche grazie ai metodi del digital heritage. L'esigenza di connettere gli individui e le comunità alle diverse espressioni della loro identità e diversità culturale pone una serie di questioni nello scenario contemporaneo del turismo globale, ad esempio sui processi di riappropriazione che le rappresentazioni possono indurre. La riproduzione dei patterns e dei codici utilizzati per i tessuti, la descrizione analitica del procedimento di fabbricazione della "tenda nera" (quella tipica delle popolazioni beduine arabiche occidentali), l'inquadramento antropologico di una cultura fragile e dei suoi oggetti significativi, la trasmissione dei suoi saperi pratici e dei mestieri tradizionali, costituiscono i fondamenti di una prossima biblioteca vivente, da allestire nei musei di Amman.

Parole chiave

cultura beduina; folklore; rappresentazione dell'intangibile; digital heritage; biblioteca vivente.

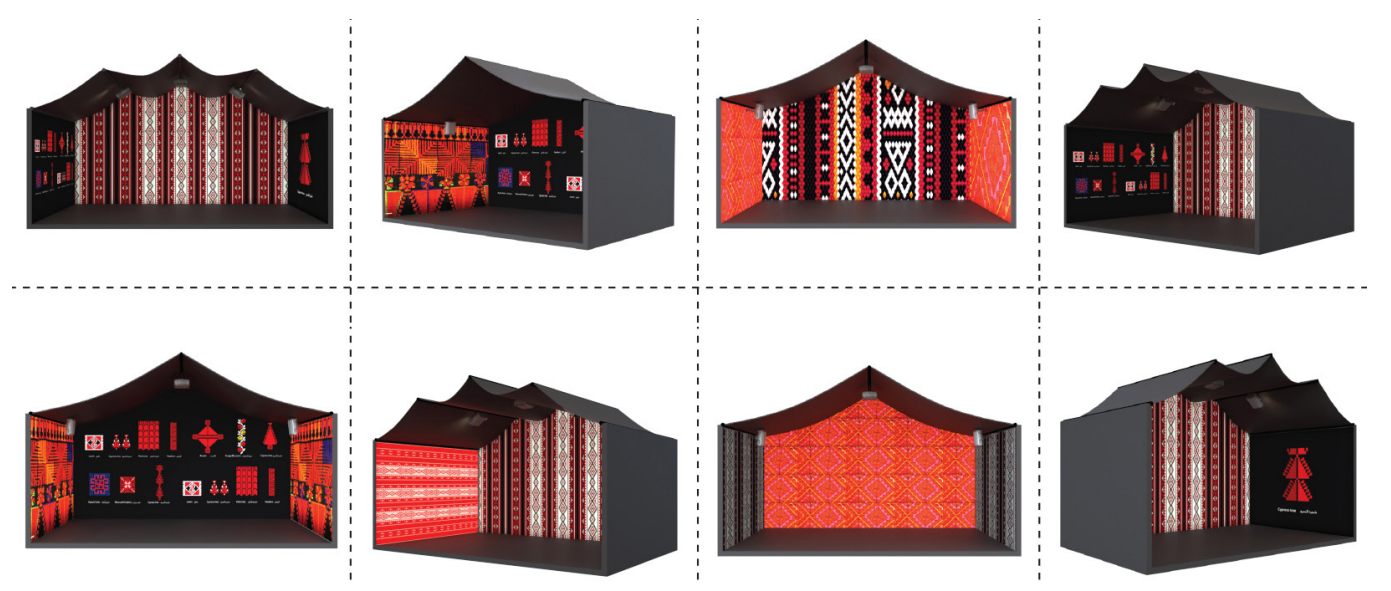




\section{Introduzione}

II patrimonio culturale, secondo la Convenzione di Faro, è una raccolta di risorse ereditate dal passato che le persone identificano come espressione dei propri valori, credenze, conoscenze e tradizioni in continua evoluzione. La valutazione da parte delle comunità di quali sono gli elementi simbolici della loro identità, che sarebbe opportuno sostenere e trasmettere, rappresenta la cerniera tra gli studi storici, la conoscenza, l'eredità ed il futuro sviluppo economico di un territorio che vuole essere attrattivo [Zagato 20I5].

Proteggere quel patrimonio, composto dai diversi domini dell'espressione umana, vuol dire trasferire alle nuove generazioni quelle capacità creative e di immaginazione che gli consentiranno di rigenerare valori e significati in maniera autentica e contribuire al mantenimento della memoria collettiva dell'umanità.

Un passo importante nella strategia dell'UNESCO è la proclamazione, nel 200I, dei Masterpieces of the Oral and Intangible Heritage dopo un lungo processo di definizione degli strumenti per la salvaguardia del patrimonio vivente e come testimonianza della cultura immateriale del mondo. L'esperienza acquisita attraverso questo programma ha permesso il rilascio della Convenzione per la salvaguardia del patrimonio culturale immateriale, entrata in vigore nel 2006. Tale programma nasce per incoraggiare le comunità locali a proteggere il patrimonio collettivo e gli individui nelle diverse forme di espressione culturale. Si tratta di rappresentare un patrimonio radicato nella tradizione culturale o nella storia culturale della comunità per favorire la consapevolezza e lo sviluppo dell'identità culturale della comunità.

\section{Rappresentare il paesaggio culturale della tenda nera come bene comune}

Lo scopo del progetto è contrastare il fenomeno sociale che allontana le popolazioni dalla propria cultura e territorio, in un contesto globale che impone stili di vita non sostenibili e perdita di competenze e cultura materiale. La sua distruzione o ricostruzione rivela come il paesaggio o la bellezza comune possano simboleggiare la civiltà che lo ha creato, ma anche i suoi fallimenti. Il progetto sottolinea il ruolo della scelta pubblica sulle decisioni che influenzano la produzione di beni e servizi pubblici, coinvolgendo le comunità locali nella continua sfida di modellare il proprio paesaggio a beneficio di un'identità collettiva, diffusa e condivisa [Ostrom 1990].

Gli obbiettivi sono rafforzare la consapevolezza sull'identità e le tradizioni locali connettendo le persone al patrimonio, sviluppare competenze nella rappresentazione del patrimonio culturale con particolare attenzione ai nuovi linguaggi e tecnologie per migliorare l'accessibilità e la comunicazione dei beni, sperimentare applicazioni intelligenti per sistemi museali e siti archeologici in grado di valorizzare il patrimonio attraverso strategie espositive e di interazione per un'esperienza multi-utente efficace.

Richard Sandell richiama il concetto di responsabilità sociale delle istituzioni culturali e museali, laddove queste esercitino attivamente il ruolo d'inclusione sociale all'interno di una comunità: gli studi, in particolare, hanno evidenziato come spesso i musei costituiscono "luoghi esclusivi" di accesso alla cultura, creando barriere psicologiche, economiche, materiali e sociali, e non stimolando positivamente le comunità e i loro individui [Sandell 1998]. Nel progetto di ricerca proposto le azioni di trasformazione digitale delle collezioni museali dei due musei giordani attualmente disposte senza alcun ausilio tecnologico, hanno dunque lo scopo di supportare i curatori nell'agire in maniera responsabile. II museo può così diventare un agente di trasformazione sociale superando le cause di esclusione (rappresentazione, la partecipazione e l'accesso, secondo Sandell) e favorendo quelle di inclusione attraverso le diverse dimensioni culturali dell'interazione: modelli, disegni di illustrazione, esperienza tattile, racconto e videomapping.

La Netherlands Museums Association ha magistralmente qualificato la sequenza dei valori che costituiscono il significato sociale di un museo. Tra i cinque, Collection, Connecting, Education Experience, Economic, sicuramente il più strategico è quello del connettere che sta nella capacità del museo di agire come connettore e mediatore tra diversi gruppi all'interno della 


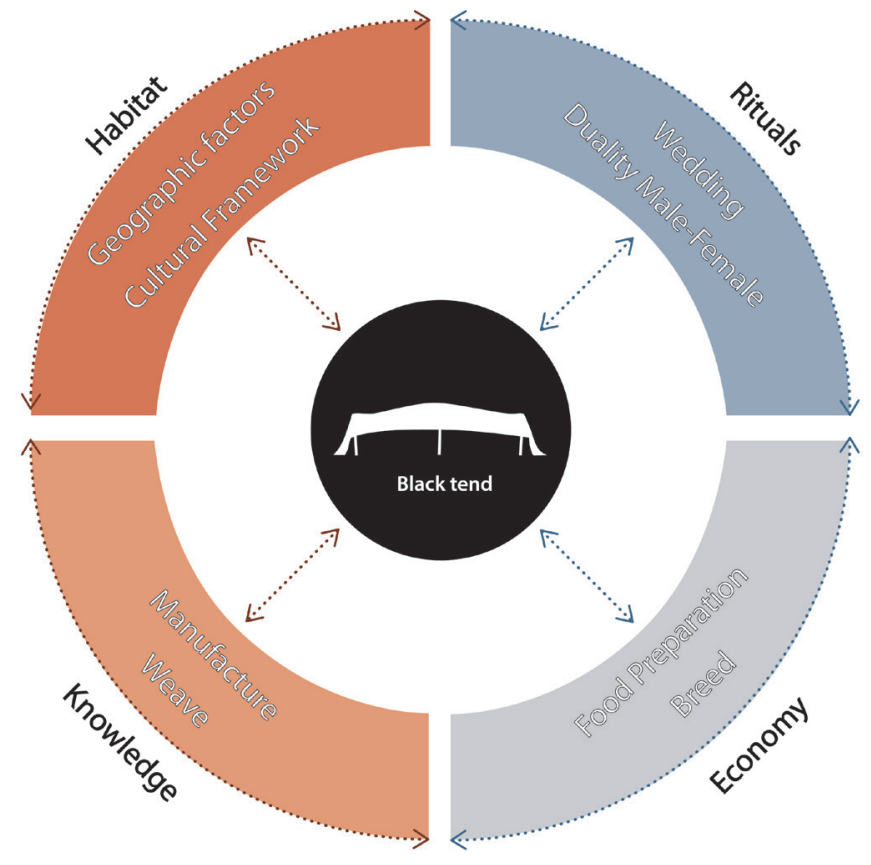

società e di diventare un medium per la comunicazione e il confronto, entrando in collaborazione con differenti stakeholder.

Superando il concetto del valore della collezione, spesso secondario, la connessione s'instaura proprio tramite il valore educativo, laddove il museo si configura come un ambiente di apprendimento formale e informale per i diversi profili di utenti, o personas, ma anche come luogo di divertimento e conoscenza [Weide 20l I].

Gli spazi della cultura, per compiere la propria missione educativa, hanno bisogno di andare oltre la dimensione tangibile e sensoriale comune per comunicare e condividere il patrimonio inteso anche nella dimensione intangibile tramite la sua riappropriazione, sfruttando le leve emozionali e attitudinali all'interno di una comunità (fig.l).

\section{II sistema costruttivo della tenda nera, connessione tra habitat e folklore}

I Bedu sono comunità stanziale e nomade che vive nella parte meridionale della Giordania, in particolare vicino a Petra e nel Wadi Rum, all'interno di una regione di altopiani semi-aridi e deserti. Mantengono viva una cultura pastorale tradizionale e le relative abilità, come la conoscenza specifica legata alla flora, alla fauna, alla medicina tradizionale e all'allevamento di cammelli, fabbricazione di tende e altre abilità artigianali. I Bedu hanno sviluppato un'ampia conoscenza del loro ambiente e conservano un codice morale e sociale complesso, che si trasmette nel contesto famigliare. La loro ricca mitologia e iconografia (basti pensare alla figura di Lawrence d'Arabia e alla costruzione dell'immaginario mediorientale) si manifesta in varie forme di espressione orale, compresa la poesia, i racconti popolari e il canto a cui è strettamente legata la storia ed i luoghi di queste comunità.

La tesi etnografica di Feilberg costituisce un riferimento assoluto per stimare le loro origini. Feilberg osserva - anche supportando le affermazioni dell'orientalista Alois Musil - che i beduini Rwala dividono l'umanità in Hazar, quelli che vivono nelle case, e gli Arab, quelli che vivono nelle tende nere e quindi popolazioni nomadi. Gli Hazar sono ulteriormente divisi in Qarawne, che abitano sedentariamente i loro villaggi, e i Ra'w, che viaggiano stagionalmente con le loro greggi per garantirsi la sussistenza economica che vive dei pascoli. Gli Arab si dividono in Swaya, che allevano capre e pecore, e beduini veri e propri, che allevano cammelli [Feilberg 1944]. 
Molta della cultura beduina si esprime negli elementi materiali, quegli oggetti che accompagnano i rituali sociali come motivi tribali centrali nell'identificazione nazionale giordana. I motivi principali sono la tenda, la caffettiera, il cammello (o dromedario) in aggiunta agli abiti beduini e al folklore; tra questi la costruzione artigianale della tenda, sistema costruttivo, abito e abitudine nella vita nomadica di tali comunità, è stata assunta come simbolo universale ed autentico dell'umanità.

La tenda è stata ampiamente descritta come costruzione paradigmatica dell'abitare temporaneo e nomadico secondo un concetto di architettura collaborativa, dove partecipano uomini e donne della comunità. Antropologi ed esperti come Torvald Faegre offrono molti documenti per lo studio dell'architettura nomade, i cui elementi strutturali connettono permanentemente le qualità di impermanenza e gerarchia stabilita nell'adattamento millenario ai climi desertici [Faegre 1979] (fig. 2). Il suo sistema si rappresenta come national signifier, oggetto, tecnica e prodotto culturale di cui investigare le cause e trasmetterle nel dominio globale perché possano ancora trasmettersi. La tenda, beit sha'r (casa di pelo), serve per proteggere dal sole, dal freddo e dalla sabbia, e permette la vita privata dei suoi abitanti. II tessuto nero è funzionale per il colore e per la fattura di lana di capra. II nero fa più ombra e mentre assorbe più calore, la trama larga del tessuto lo disperde. La stessa trama con l'umidità delle piogge o della notte, s'inspessisce chiudendo gli interstizi e diventando impermeabile anche grazie al grasso naturale del pelo. II tessuto è formato da diverse strisce cucite tra loro, larghe come il telaio che le realizza e lunghe dai I0 a i I5 metri quanto la lunghezza della tenda, ed è rinnovato ogni 5 anni circa; è appoggiato su pali, almeno 3, teso e ancorato a terra attraverso funi di canapa, attaccate ad una staffa a sua volta assicurata ad una banda che cucita trasversalmente alle strisce di tessuto, distribuisce la tensione su una area più ampia evitando lo strappo della tela. La grandezza della tenda, che rappresenta la ricchezza e la posizione sociale del suo proprietario, dipende dal numero dei singoli teli che la formano; questi sono tessuti da una donna che lavora sola e cuciti insieme da un gruppo di donne. Questa operazione dà vita ad una nuova tenda ma concettualmente ad una nuova famiglia, come l'incrocio dei tirati di due tende distinte esprime un qualche legame tra i loro proprietari $($ figg. 3,4$)$.

La comunità beduina, socialmente articolata per famiglie, ruota attorno a due sfere principali, pubblica e privata, che regolano la vita quotidiana e che devono rimanere separate affinché rimangano in equilibrio. La caratteristica fisica della tenda rispecchia questo dualismo: è divisa in due sezioni la cui dimensione dipende sia dalla grandezza della tenda sia dalle necessità degli abitanti. La prima sezione, orientata a est, è quella maschile chiamata al shigg, dove si ricevono e intrattengono gli ospiti e si narrano tradizioni accompagnati dal suono del rababah; con l'apertura rivolta verso solitamente a sud o verso la Mecca viene

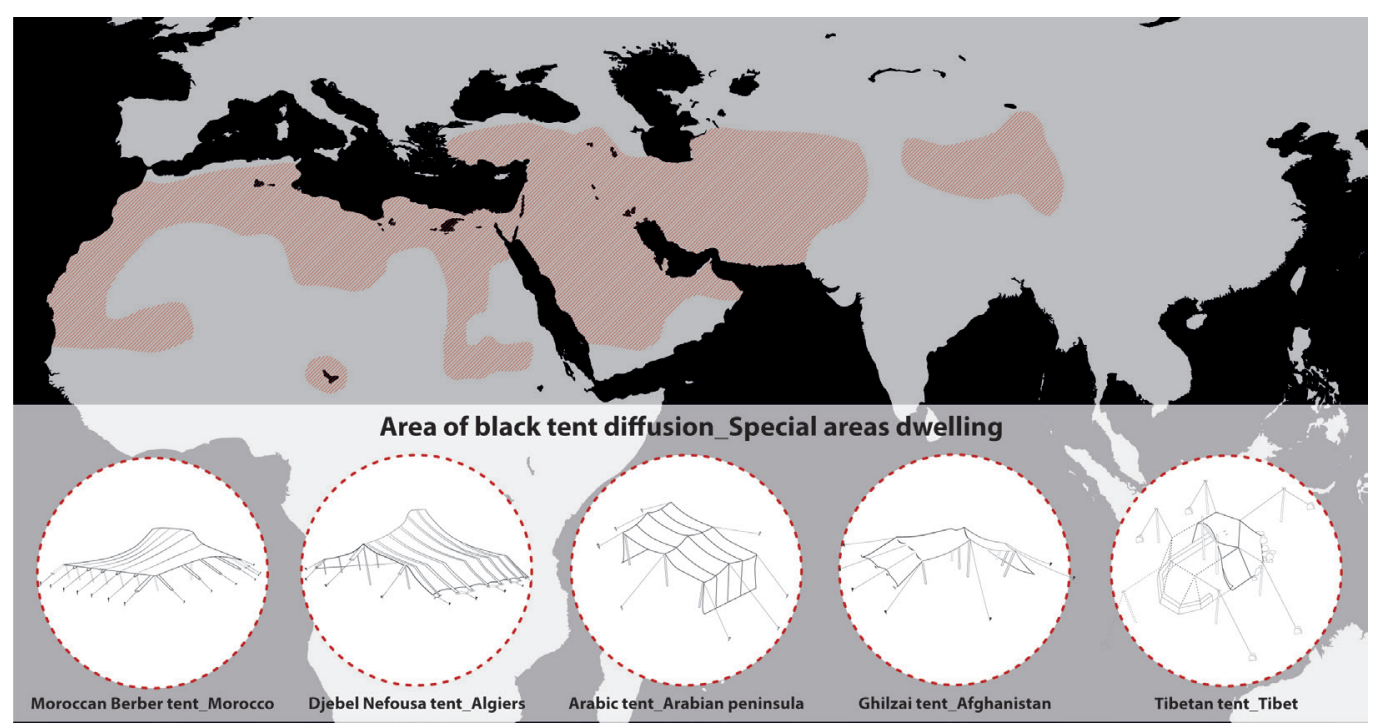




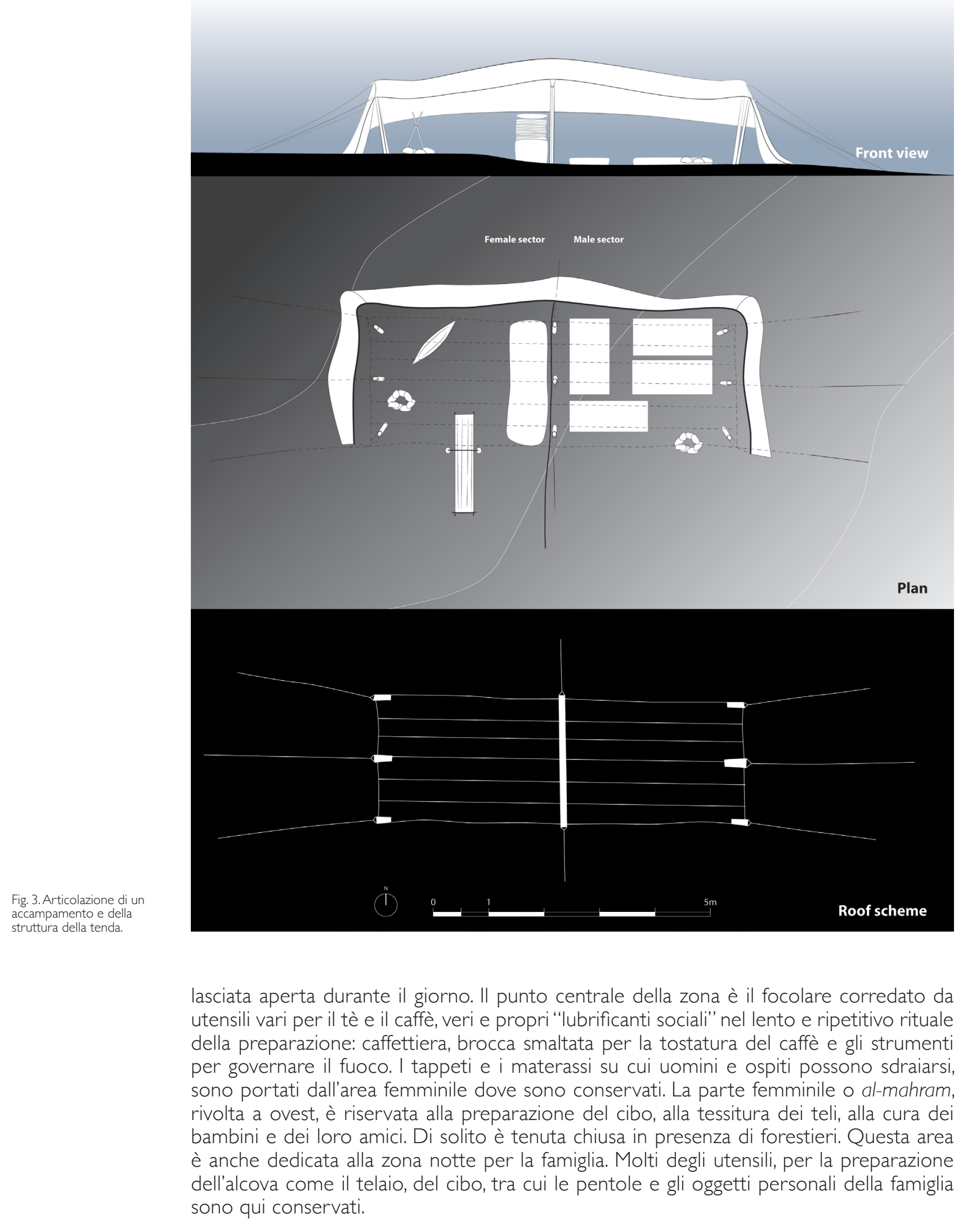




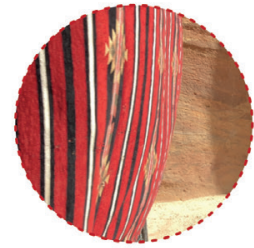

Ru'ag or Al-Rifraf Side interior walls

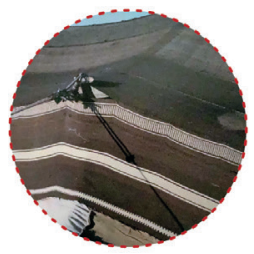

Al-Ruaq or Qa Disi Back wall

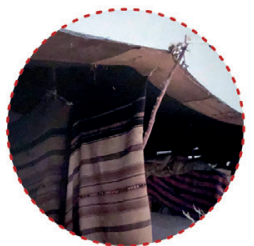

Sah $h$ Interior curtain

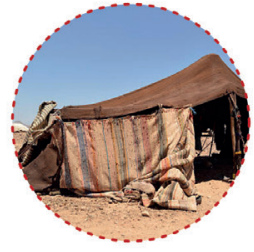

Al-Ghidfa Front curtain

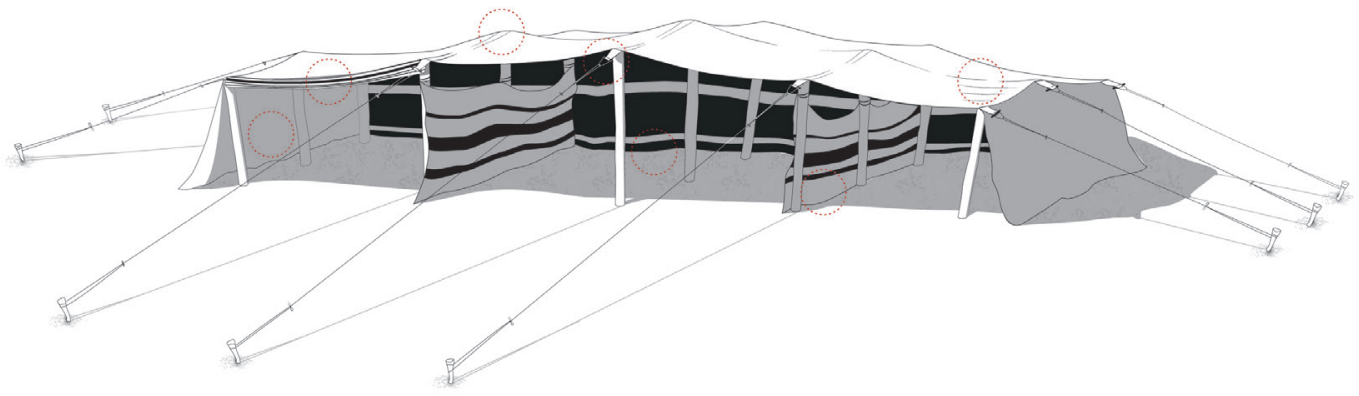

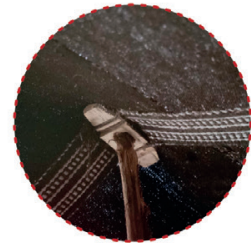

Sabab

Tension band

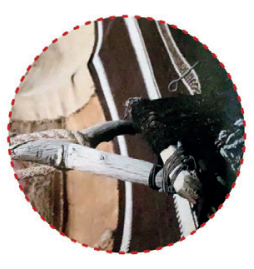

Rit bah

Stay fastener

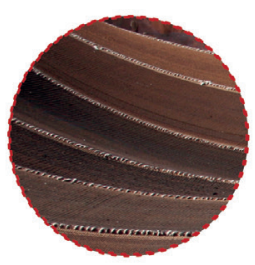

Shiqaq

Strips of wool

La distribuzione riflette il sistema socioculturale beduino. La privacy non è un concetto individuale ma collettivo: le tende proteggono le donne da interazioni non volute con gli uomini e sono il comune confine fisico che divide i due spazi, mentre tenda non costituisce un netto limite tra l'interno e l'esterno lasciando un dialogo costante con l'ambiente circostante. Le interazioni al suo interno dipendono dall'età, sesso e dalla relazione genealogica. Sebbene molti beduini oggi non vivano più in tende, l'organizzazione spaziale delle case moderne è basata sulle funzioni legate al genere. La divisione riflette l'orientamento sociale verso regole patriarcali. Le donne sono protette nel codice d'onore e l'onore e la reputazione di tutta la famiglia e della tribù dipende dall'onore delle donne. I bambini posso muoversi all'interno della tenda liberamente, ma le ragazze all'età dell'adolescenza devono osservare le stesse regole delle donne. L'illustrazione dettagliata di tale sistema abitativo permette di rappresentare geograficamente le regole sociali, millenarie ma anche moderne nel continuo della tenda alla vita globale, con una maggiore integrazione con i villaggi e con un quotidiano sedentario, che mette a rischio la sopravvivenza di tale identità (fig. 5).

\section{Biblioteca digitale dei maestri artigiani, dei mestieri e delle arti tradizionali giordane}

Il progetto propone di costituire una collezione digitale di racconti orali degli artigiani, dei maestri costruttori, degli artisti e di tutti coloro che ancora oggi permettono di tramandare le più antiche e popolari tradizioni giordane. Nella sua accezione più elevata I'installazione di una Biblioteca Vivente, avviene attraverso la partecipazione delle persone a forme laboratoriali e di interazione, ovvero nel progetto specifico come esperimento 
di trasformazione digitale tramite la video registrazione di interviste per rendere universalmente nota la storia orale, conoscere gli antichi mestieri, toccare con mano le materie prime che le popolazioni e gli artigiani lavorano per trasformarle in prodotti, simboli, rituali, cultura materiale.

Una biblioteca vivente, nell'idea originaria, funziona come qualsiasi biblioteca; i libri, tuttavia, sono persone in carne e ossa che condividono oralmente un aspetto della loro identità e del loro sapere. Il progetto vuole pertanto supportare la conoscenza degli artigiani tra i più abili che lavorano con maestria in diverse discipline artigianali in tutta la Giordania, tra cui la produzione dei tessuti, il ricamo e la ideazione di gioielli, la produzione di oggetti tradizionali ovvero la produzione artistica tradizionale come la lavorazione del legno, l'intarsio in madreperla, il mosaico in legno, le sculture in legno e le lavorazioni in metallo. L'obiettivo è quello di sviluppare un inventario di significant objects. Gli oggetti e le espressioni artistiche che questi artigiani producono testimoniano il ricco patrimonio della regione, nonché il potenziale di innovazione degli artigiani e delle donne di oggi. Il progetto mira a formare una nuova generazione di artigiani giordani, che riconoscendo le loro tradizioni, possano creare una massa critica di figure professionali attrezzate per mantenere queste importanti tradizioni culturali. La biblioteca digitale garantisce il mantenimento e la trasmissione di queste abilità e intelligenza pratica affinché siano sostenuti e trasmessi alle nuove generazioni attraverso iniziative di formazione e curricula che possano mettere assieme i fabbisogni degli operatori turistici con lo sviluppo locale e la microimpresa creativa dedicata alla produzione di nuovi prodotti, oggetti ed espressioni artistiche. (figg. 6,7)

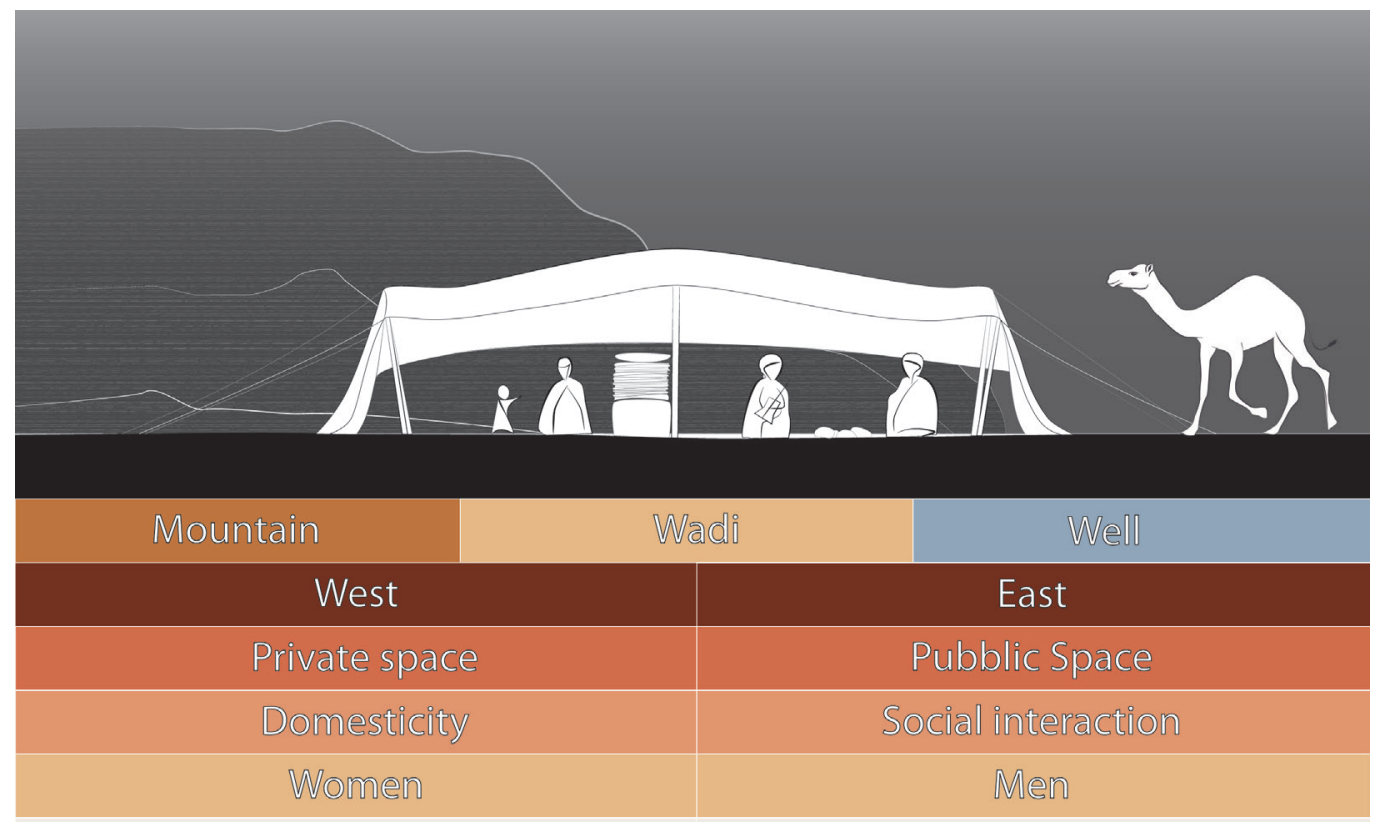

Behind the curtein

Fipe Place

$\begin{array}{cc}\text { Behind the curtain } & \text { Fire Place } \\ \text { Bread making_Food preparation } & \text { Coffe preparation } \\ \text { Weaving } & \text { Welcoming guest } \\ \text { Sleeping_Bathing_Child care } & \text { Narration and Music }\end{array}$
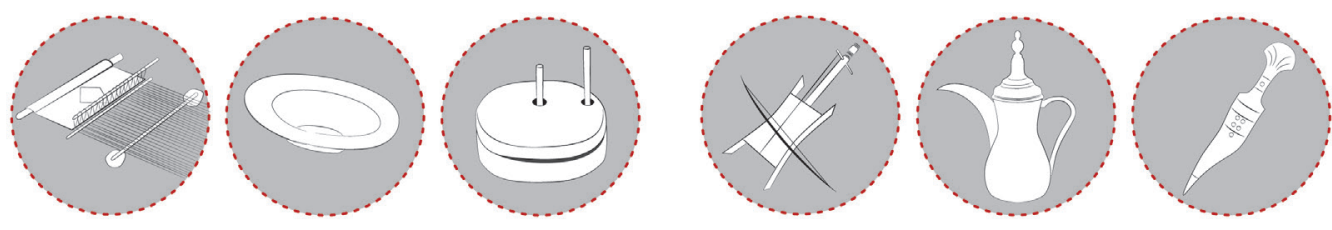

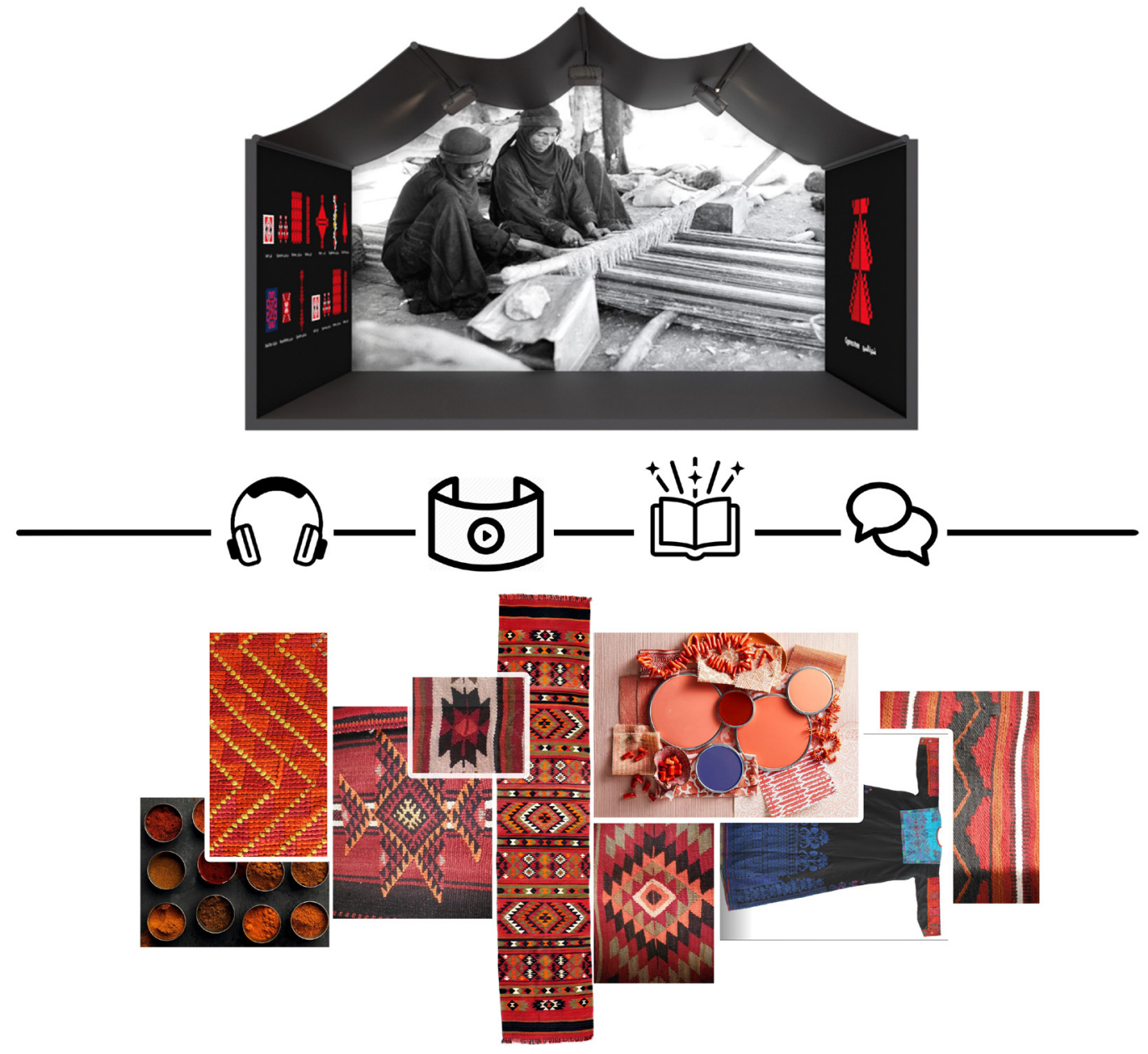

\section{Conclusioni}

La ricerca operativa inquadra metodologicamente il processo di rappresentazione dell'intangibile e di comunicazione del paesaggio culturale legato alla cultura beduina, da considerare come un fenomeno sociale, che opera su aspetti percettivi ed emotivi, e come fatto culturale, del quale evidenziare quegli strati che ne giustificano la sua rilevanza. II processo vuole amplificare il ruolo delle istituzioni museali nella responsabilità di ridurre o eliminare le eventuali barriere all'inclusione sociale. Per rappresentare una cultura, così geograficamente radicata, occorre mappare e identificare i suoi codici e descrivere con gli strumenti del disegno i saperi come testimonianza di una tradizione culturale vivente per affidarne la custodia alle generazioni contemporanee. La ricerca propone un modello metodologico di lettura, interpretazione e narrazione dell'identità locale creando una connessione articolata di saperi e di espressioni materiali attraverso i sistemi digitali di ultima generazione. II procedimento sarà sperimentato presso il Teatro Romano di Amman nella riqualificazione dei musei della cultura giordana in un programma di cooperazione internazionale e progettazione collaborativa. 
Fig. 7. Biblioteca digitale della cultura immateria beduina e dei saperi tradizionali.
The typology of bedouin loom
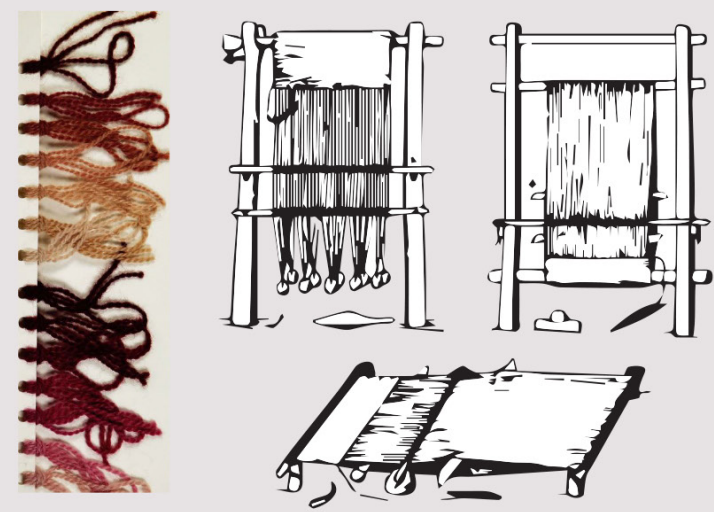

Digital library
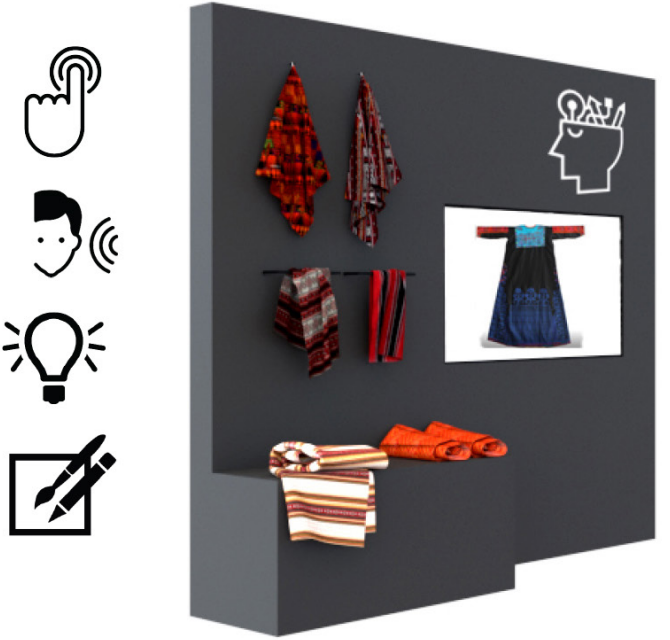

Typological pattern of bedouin textile

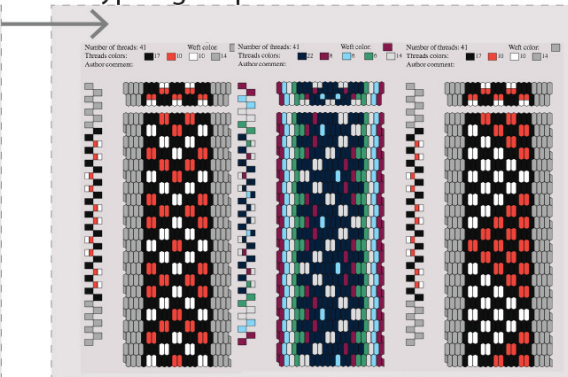

The typology of costumes
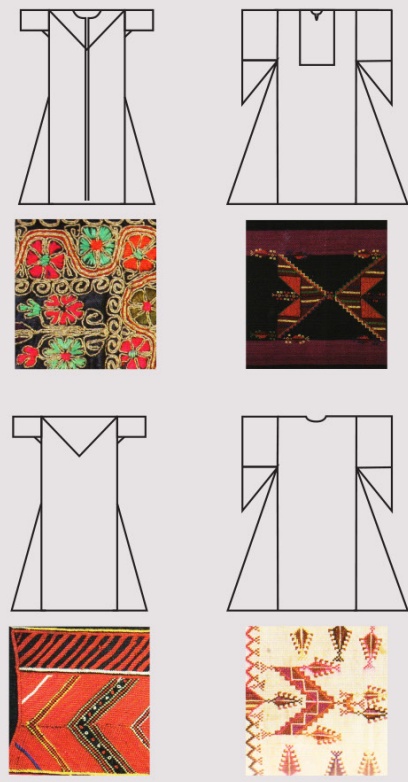

\section{Crediti}

Questo lavoro fa parte del progetto di ricerca e cooperazione internazionale: Program for the definition of a strategic plan for the improvement and the enhancement of the Folklore Museum, the Museum of PopularTraditions and the site of the Roman Theatre in Amman avviato nel 2020. Giuseppe Amoruso è il responsabile scientifico e autore dei paragrafi 'Introduzione' e 'Rappresentare il paesaggio culturale della tenda nera come bene comune'; Sara Conte ha sviluppato il paragrafo 'll sistema costruttivo della tenda nera, connessione tra habitat e folklore' e le illustrazioni; Polina Mironenko è autore del 'Biblioteca digitale dei maestri artigiani, dei mestieri e delle arti tradizionali giordane' e le relative illustrazioni.

\section{Riferimenti bibliografici}

Amoruso G., Mironenko P. (2019). Heritage BIM descriptive models for the representation of resilient city. The case of Amatrice's reconstruction. In P. Belardi (a cura di). Riflessioni, L'arte del disegno/ll disegno dell'arte. Atti del $41^{\circ}$ Convegno internazionale dei Docenti delle discipline della Rappresentazione. Perugia, 19-2I settembre 20 I9. Roma: Gangemi, pp. I05 I - 056.

Amoruso G., Mironenko P. (2020). Memory as a Common Asset. Algorithmic Generative Representations for the Reconstruction of the Community Identity after the Earthquake. In A. Arena et al. (a cura di). Connettere/un disegno per annodare e tessere. Atti del $42^{\circ}$ Convegno internazionale dei Docenti delle discipline della Rappresentazione, tenutosi online il 18 settembre 2020. Milano: FrancoAngeli, pp. I528- 1537.

Biasutti R. (1962). II paesaggio terrestre. Torino: Utet.

Cappelletto C. (20।0). La natura funzionale dell'immagine nel confronto con le neuroscienze. In PsicoArt - Rivista di Arte e Psicologia, I ( 1 ).

Convenzione di Faro. (2005). Value of cultural heritage for society. Council of Europe Framework-Convenzione quadro del Consiglio d'Europa (CETS no. 199), 18, 03-08.

Eco U. (20 I 3). Mnemotecniche e rebus. Rimini: Guaraldi San Marino University Press. 
Erasmo V. (2020). Homo capabilitiensis: un paradigma antropologico per il futuro ispirato alla riflessione di Amartya Sen. In Alici, L., Miano, F. (a cura di) L'etica nel futuro. Roma: Orthotes Editrice pp. 455-464.

Lapiccirella Zingari V. (2015). Patrimoni vitali nel paesaggio. Note sull'immaterialità del patrimonio culturale alla luce delle Convenzioni internazionali. In L. Zagato, M.Vecco (a cura di). Citizens of Europe. Culture e diritti,Venezia: Cà Foscari Edizioni, pp. 425-456.

Marrazzo D. (28 febbraio 202 I). De Luca, l'architetto che restaura Notre Dame con 3D, digitale e videogame. In ilSole24ore. $<$ https://www.ilsole24ore.com/art/de-luca-l-architetto-che-restaura-notre-dame-3d-digitale-e-videogame-ADVsOrMB?refresh_ce= $\mid>$ (consultato il 6 aprile 202I)

Mironenko P. (2019). Conservation Issues on UNESCO World Heritage Sites in Russia. From the Roerich Pact to Contemporary Challenges. In Amoruso G., Salerno R. (a cura di) Cultural Landscape in Practice. Lecture Notes in Civil Engineering, vol 26. Springer, Cham.

Sacks O. (2017). Il fiume della coscienza. Milano: Adelphi.

Spangerberg J. ( 1539). Artificiosae Memoriae Libellus... Lipsiae: Impressum per Michaelem Blum.

Tarasco A.L. (2004). Beni, patrimonio e attività culturali: attori privati e autonomie territoriali. Napoli: Editoriale Scientifica.

UNESCO. (2003). Convenzione per la salvaguardia del patrimonio culturale immateriale. Trad. it. <https://ich.unesco.org/docl src/00009-IT-PDF.pdf> (consultato il 24 aprile 202I).

UNESCO. (2005). Convenzione per la salvaguardia del patrimonio culturale immateriale. <https://delegazioneunesco.esteri.it/rappunesco/it/i-rapporti-bilaterali/informazioni-e-servizi/salvaguardia-patrimonio-culturale-immateriale> (consultato il 10 maggio 202I).

UNESCO. (20I I). Recommendation on the Historic Urban Landscape. <https://whc.unesco.org/en/hul/> (consultato il 24 aprile 202I).

\section{Autori}

Giuseppe Amoruso, Politecnico di Milano, giuseppe.amoruso@polimi.it

Sara Conte, Politecnico di Milano, sara.conte@polimi.it

Polina Mironenko, Politecnico di Milano, polina.mironenko@polimi.it

Per citare questo capitolo: Amoruso Giuseppe, Conte Sara, Mironenko Polina (2021). Rappresentazione dellintangibile, cultura beduina e tecnologie per connettere/Representation of the Intangible, Bedouin Culture and Technologies to Connect. In Arena A. Arena M., Mediati D. Raffa P (a cura di) Connettere Un disegno per annodare e tessere. Linguggri Distanze Tecnologie Atti del $42^{\circ}$ Convegno Internazionale dei Docenti delle Discipline della Rappresentazione/Connecting. Drawing for weaving relationship. Languages Distances Technologies. Proceedings of the 42 th International Conference of Representation Disciplines Teachers. Milano: FrancoAngeli, pp. 1902-1921. 


\title{
Representation of the Intangible, Bedouin Culture and Technologies to Connect
}

\author{
Giuseppe Amoruso \\ Sara Conte \\ Polina Mironenko
}

\section{Abstract}

How to reveal through a set of representations the primitive living concept rooted in the origins of humanity? What are the codes of nomadic populations that characterize the Jordanian identity? The research on the representation of intangible heritage aims to connect cultural expressions and facts that have been rooted in Bedouin culture for centuries as an economic and social tradition of adaptation to the Middle Eastern habitat. The occasion arises from an international cooperation project aimed at enhancing the museum collections of the Folklore and PopularTraditions museums at the Roman Theater in Amman.

The museum layout strategy promotes the transformation of spaces into places of knowledge and experience also thanks to digital heritage applications. The need to connect individuals and communities to the different expressions of their identity and cultural diversity raises a number of questions in the contemporary scenario of global tourism, for example on the re-appropriation processes that representations can induce. The patterns and codes reproduction as found in the traditional textiles, the analytical description of the 'black tent' manufacturing process (as traditional in the Western Arabian Bedouin populations), the anthropological framework of a fragile culture and its significant objects, the transmission of its practical knowledge and traditional crafts, constitute the foundations of an upcoming digital library, to be set up in the museums of Amman.

Keywords

Bedouin culture; folklore; representation of the intangible; digital heritage; living library.

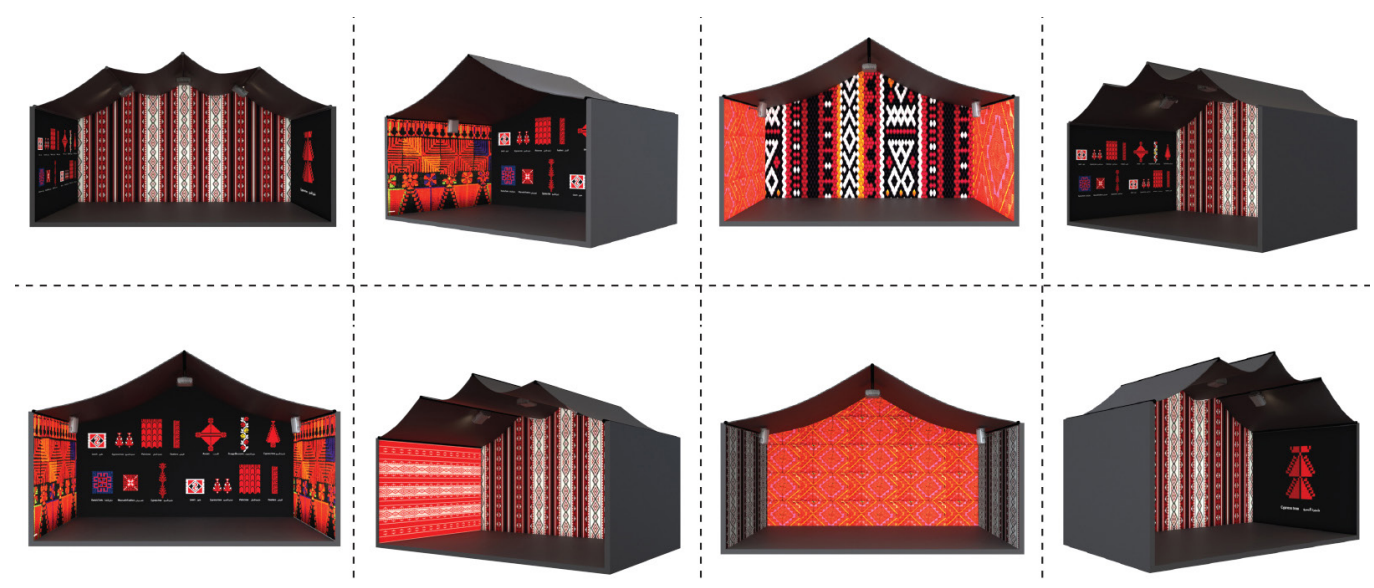




\section{Introduction}

Cultural heritage, according to the Faro Convention, is a collection of resources inherited from the past that people identify as an expression of their ever-changing values, beliefs, knowledge and traditions. The evaluation by the communities of which are the symbolic elements of their identity, which it would be appropriate to support and transmit, represents the link between historical studies, knowledge, heritage and the future economic development of a territory that wants to be attractive [Zagato 20 I5].

Protecting that heritage, as a mosaic of different domains of human expression, is a process of inclusion of new generations; their creative and imaginative abilities will allow them to authentically regenerate popular values and collective meanings and to contribute to maintaining the collective memory of humanity.

An important step in UNESCO's strategy is the proclamation, in $200 \mathrm{I}$, of the Masterpieces of the Oral and Intangible Heritage after a long process of defining the tools for safeguarding living heritage and as a testimony of the world's intangible culture. The experience gained through this program has allowed the release of the Convention for the Protection of Intangible Cultural Heritage, which was released in 2006. This program was created to encourage local communities to protect the collective heritage and individuals in the various forms of cultural expression. It is about representing a heritage rooted in the cultural tradition or cultural history of the community to promote awareness and development of the cultural identity of the community.

\section{Representing the cultural landscape of the black tent as a common good}

The aim of the project is to oppose the social phenomenon that distances populations from their own culture and territory, in a global context that imposes unsustainable lifestyles and the loss of skills and material culture. Its destruction or reconstruction reveals how common landscape or beauty can symbolize the civilization that created it, but also its failures. The project underlines the role of public choice on decisions that influence the production of public goods and services, involving local communities in the continuous challenge of shaping their landscape for the benefit of a collective, diffused and shared identity [Ostrom 1990].

The main goal is to strengthen awareness of local identity and traditions by connecting people to heritage, develop skills in the representation of cultural heritage with particular attention to new languages and technologies to improve accessibility and communication, experiment with smart applications for museums and archaeological sites able to enhance the heritage through exhibition and interaction strategies for an effective multi-user experience. Richard Sandell describes the concept of social responsibility of cultural and museum institutions, where these actively exercise the role of social inclusion within a community: studies, in particular, have highlighted how often museums are 'exclusive places' of access to culture, creating psychological, economic, material and social barriers, and not positively stimulating communities and their individuals [Sandell 1998]. In the research project, the digital transformation of museum collections of the two Jordanian museums currently exhibited without any technological device, therefore have the purpose of supporting curators in acting responsibly. Museum can thus become an agent of social transformation by overcoming the causes of exclusion (representation, participation and access, according to Sandell) and favoring those of inclusion through the different cultural dimensions of the interaction: models, illustrations, tactile experience, storytelling and video-mapping.

The Netherlands Museums Association has masterfully qualified the sequence of values that make up the social meaning of a museum. Among the five, Collection, Connecting, Education Experience, Economic, certainly the most strategic is that of connecting which lies in the museum's ability to act as a connector and mediator between different groups within society and to become a medium for communication and the comparison, entering into collaboration with different stakeholders. 


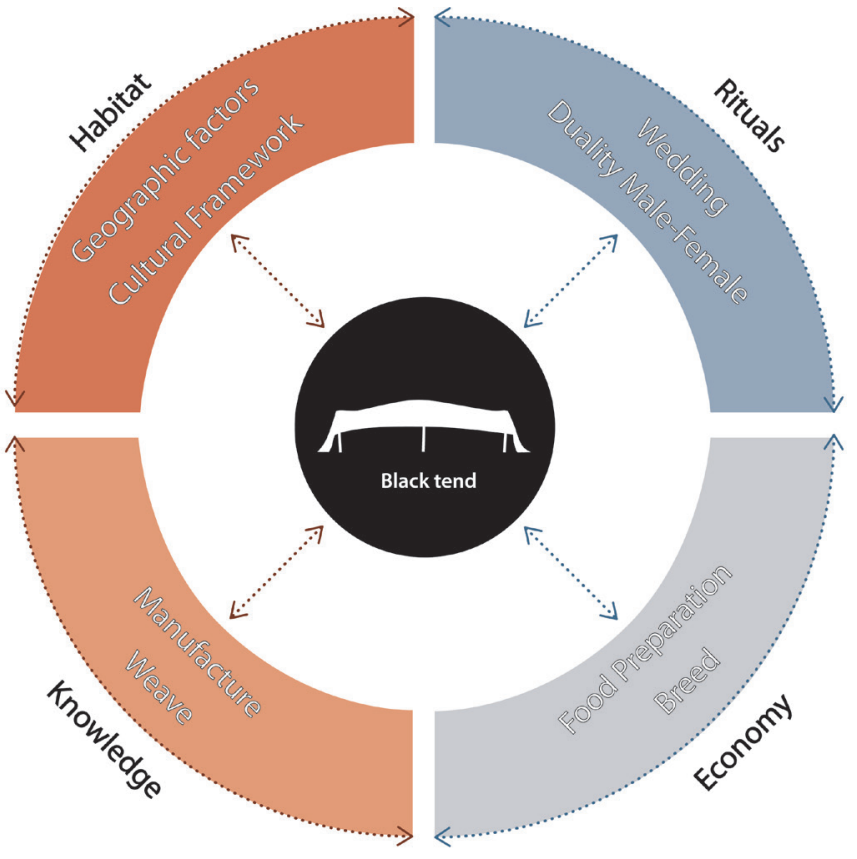

Overcoming the concept of the value of the collection, which is often secondary, the connection is established precisely through the educational value, where the museum is configured as a formal and informal learning environment for the different profiles of users, or personas, but also as a place of fun and knowledge [Weide $20 \mathrm{ll}$ ]. Cultural spaces, in order to fulfill their educational mission, need to go beyond the common tangible and haptic dimension to communicate and share heritage also in the intangible dimension through its reappropriation, exploiting the emotional and attitudinal levers within a community (fig. I).

\section{The construction system of the black tent, a nexus between habitat and folklore}

The Bedu are settled and nomadic communities living in the southern part of Jordan, in particular near Petra and in Wadi Rum, within a region of semi-arid and deserted highlands. They keep alive a traditional pastoral culture and related skills, such as specific knowledge related to flora, fauna, traditional medicine and camel breeding, tent making and other craft skills. The Bedu have developed a broad knowledge of their environment and maintain a complex moral and social code, which is transmitted in the family context. Their rich mythology and iconography (just think of the figure of Lawrence of Arabia and the construction of the Middle Eastern imaginary) manifests itself in various forms of oral expression, including poetry, folk tales and song to which the story is closely linked. and the places of these communities.

Feilberg's ethnographic thesis constitutes an absolute reference for estimating their origins. Feilberg notes -also supporting the claims of the orientalist Alois Musil- that the Rwala Bedouins divide humanity into Hazar, those who live in houses, and the Arabs, those who live in black tents and therefore nomadic populations. The Hazar are further divided into Qarawne, who sedentarily inhabit their villages, and the Ra'w, who travel seasonally with their flocks to ensure the economic subsistence that lives on pastures. The Arabs are divided into Swaya, who raise goats and sheep, and real Bedouins, who raise camels [Feilberg 1944].

Much of the Bedouin culture is expressed in the material elements, those objects that accompany social rituals as central tribal motifs in Jordanian national identification. The main motifs are the tent, the coffee pot, the camel (or dromedary) in addition to the Bedouin 
clothes and folklore; among these, the handcrafted construction of the tent, construction system, dress and habit in the nomadic life of these communities, has been taken as a universal and authentic symbol of humanity.

The tent has been widely described as a paradigmatic construction of temporary and nomadic living according to a concept of collaborative architecture, where men and women of the community share a common code. Anthropologists and experts such as Torvald Faegre offer many documents for the study of nomadic architecture, whose structural elements permanently connect the qualities of impermanence and hierarchy established in the millennial adaptation to desert climates [Faegre 1979] (fig. 2).

Its system is a representation of a national signifier, a significant object, technique and cultural product whose causes should be investigated and transmitted in the global domain so that they can still be transmitted. The tent, beit sha'r (fur house), serves to protect from the sun, cold and sand, and allows the privacy of its inhabitants. The black fabric is functional for the color and for the goat wool manufacture. Black casts more shade and while it absorbs more heat, the loose weave of the fabric disperses it. The same texture with the humidity of the rains or the night, reacts by closing the interstices and becoming waterproof also thanks to the natural fat of the hair. The fabric is made up of several strips sewn together, as wide as the frame that makes them and from 10 to 15 meters long as the length of the curtain, and is renewed approximately every 5 years; it is placed on poles, at least 3, stretched and anchored to the ground through hemp ropes, attached to a bracket in turn secured to a band that sewn across the strips of fabric, distributes the tension over a larger area avoiding the tear of the canvas. The size of the tent, which represents the wealth and social position of its owner, depends on the number of single sheets that form it; these are woven by a woman who works alone and sewn together by a group of women. This operation makes possible to build a new tent but conceptually a new family universe, as the crossing of the strings of two distinct tents expresses the bond between their owners (figs. 3,4).

The Bedouin community, socially articulated by families, revolves around two main spheres, public and private, which regulate daily life and which must remain separate so that they remain in balance. The physical characteristic of the tent reflects this dualism: it is divided into two sections whose size depends both on the size of the tent and on the needs of the inhabitants. The first section, oriented to the east, is the male one called the shigg, where guests are received and entertained and traditions are told accompanied by the sound of the rababah; with the opening usually facing south or towards Mecca, it is left open during the day. The central point of the area is the hearth equipped with various utensils for tea and coffee, real "social lubricants" in the slow and repetitive ritual

Fig. 2. Diffusion of the nomads of the black tent. Tribes predominantly occupy deserts and predesert areas. Comparison ano diferent types of dwelling related to onmental conditions.

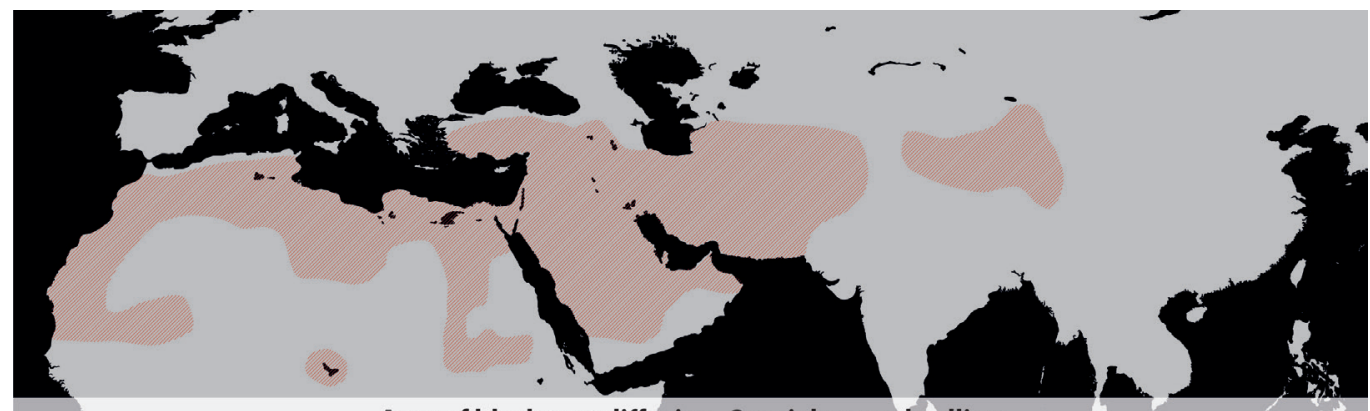

Area of black tent diffusion_Special areas dwelling

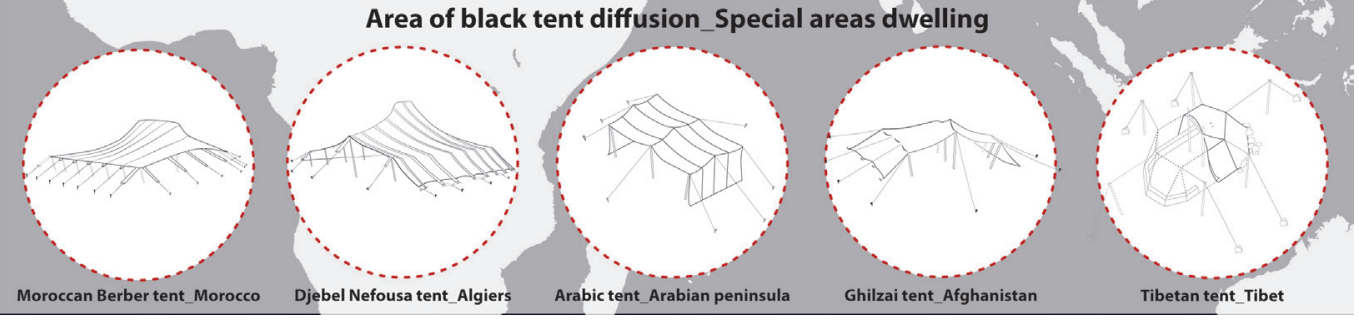




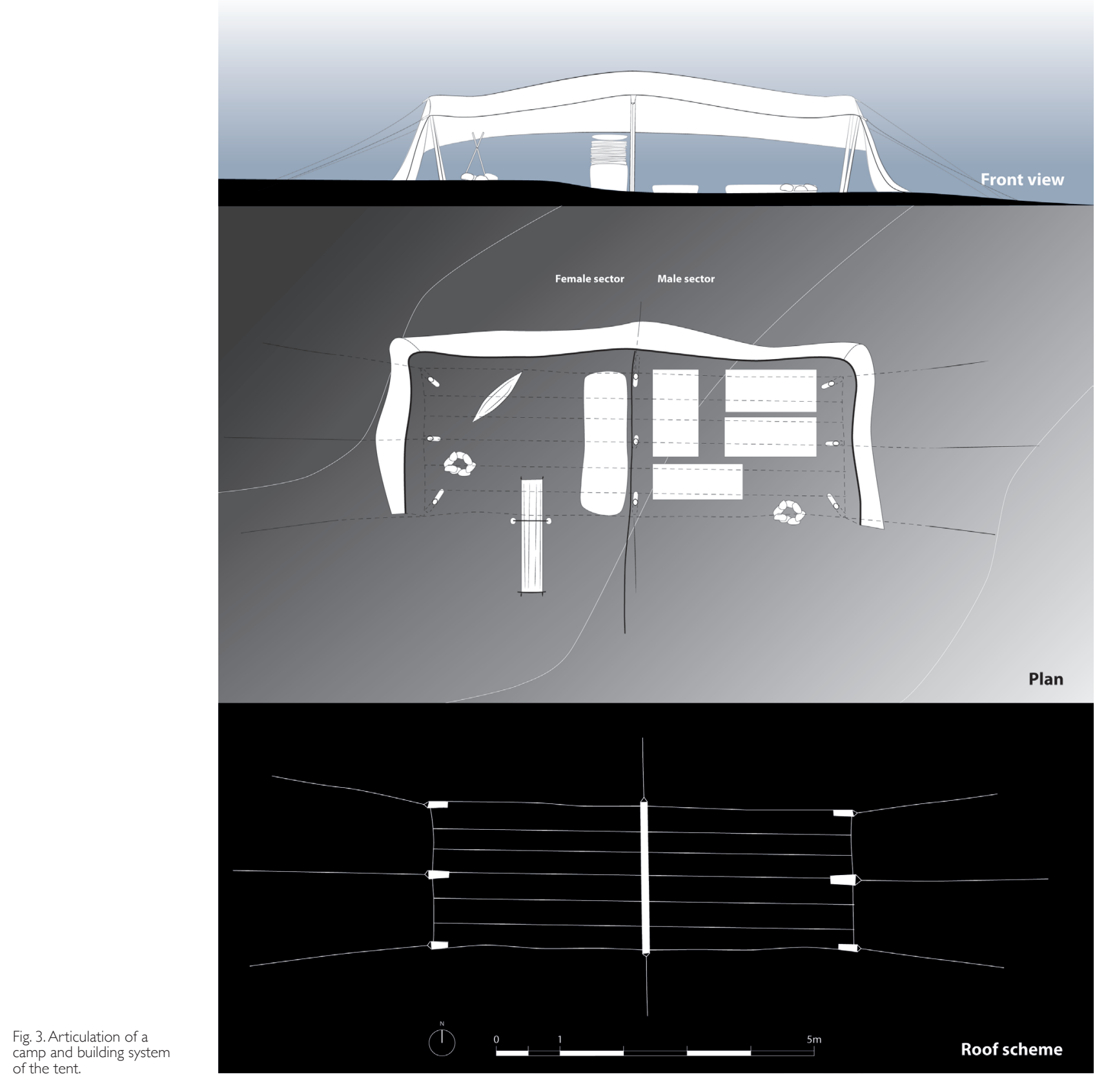

of preparation: coffee pot, enameled jug for roasting coffee and tools for governing the fire. The carpets and mattresses on which men and guests can lie down are brought from the women's area where they are stored. The female part or al-mahram, facing west, is reserved for the preparation of food, the weaving of towels, the care of children and their friends. It is usually kept closed in the presence of visiting people. This area is also dedicated to the sleeping area for the family. Many of the utensils, for the preparation of the alcove such as the loom, food, including the pots and personal items of the family are stored here.

The distribution of functions and rooms reflects the Bedouin sociocultural system where privacy is not an individual but a collective concept: curtains protect women 


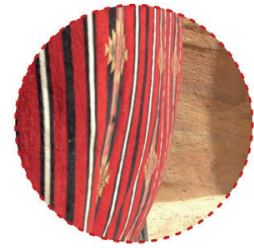

Ru'ag or Al-Rifraf Side interior walls

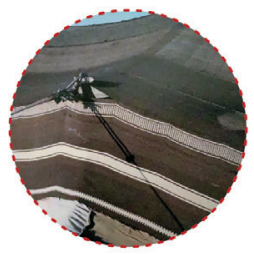

Al-Ruaq or Qa Disi Back wall

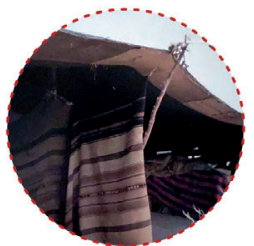

Sah $h$ Interior curtain

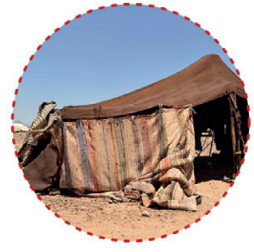

Al-Ghidfa Front curtain

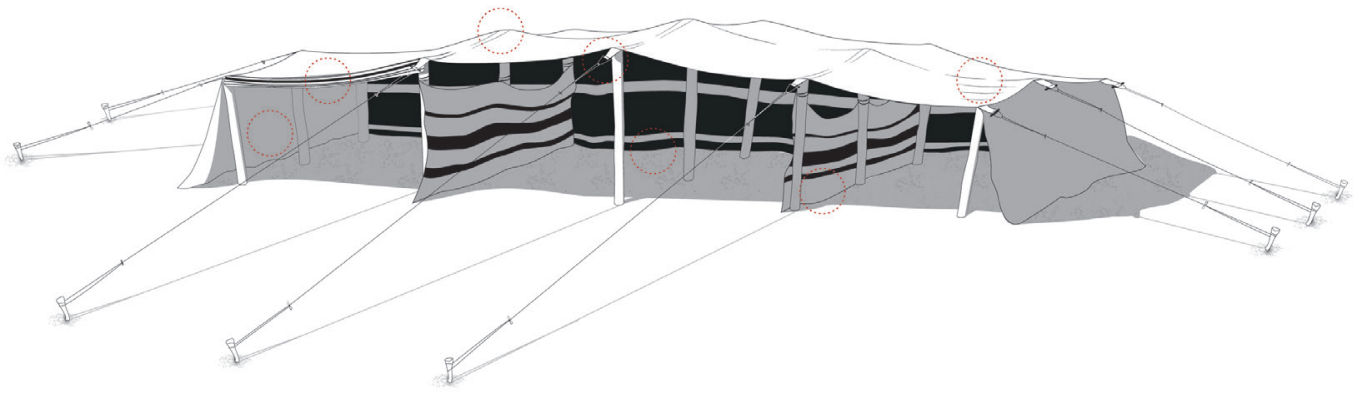

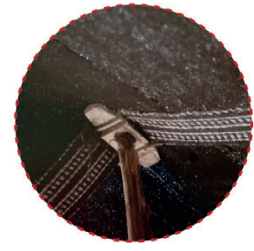

Sabab

Tension band

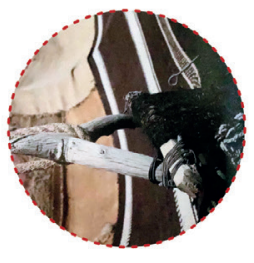

Rit bah

Stay fastener

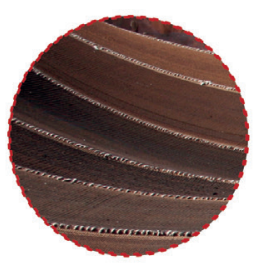

Shiqaq

Strips of wool

from inconvenient interactions with men and are the common physical buffer zone that subdivides the two environments; curtains do not constitute a clear limit between interiors and outer spaces because the surrounding environment is an extension of the tent. Interactions within such extended living environment depend on age, sex and the genealogical relationship. Although many Bedouins today no longer live in tents, the spatial organization of modern homes is based on gender-related functions. The division reflects the social orientation towards patriarchal rules. Women are protected in the code of honor and the honor and reputation of the whole family and tribe depends on the honor of women. Children can move freely inside the tent, but adolescent girls must observe the same rules as women. The detailed illustration of this housing system allows us to geographically represent the social rules, millenary but also modern in the continuation of the tendency to global life, with greater integration with villages and with sedentary daily life, which is a risk for the survival of such authentic masterpiece of identity (fig. 5).

\section{Digital library of Jordanian Master craftsmen, crafts and traditional arts}

The project proposes to create a digital collection of oral stories of the artisans, master builders, artists and all those who still today contribute to the most ancient and popular Jordanian traditions. In its highest meaning, the installation of a Living Library starts with the participation of people in workshops and interaction events, or in the specific project as an experiment of digital transformation through the video recording of interviews to make 
oral history universally known, to know the ancient crafts, touch firsthand the raw materials that the populations and artisans work to transform them into products, symbols, rituals, material culture.

A living library, in the original idea, works like any library; books, however, are real people who orally share an issue of their identity and knowledge. The project therefore aims to support the knowledge of the most skilled artisans who work with mastery in various craft disciplines throughout Jordan, including the production of fabrics, embroidery and jewelry design, the production of traditional objects or artistic production. traditional such as woodwork, mother-of-pearl inlay, wooden mosaic, wood carving and metalwork. The goal is to develop an inventory of significant objects. The objects and artistic expressions these artisans produce testify to the rich heritage of the region, as well as the innovation potential of today's artisans and women. The project aims to train a new generation of Jordanian artisans who, recognizing their traditions, can create a critical mass of professionals equipped to maintain these important cultural traditions. The digital library seeks to ensure the maintenance and transmission of these skills and this practical intelligence so that they are supported and transmitted to the new generations through training initiatives and curricula that can combine the needs of tourism operators with local development and creative micro-enterprises. dedicated to the production of new products, objects and artistic expressions. (figs. 6,7)

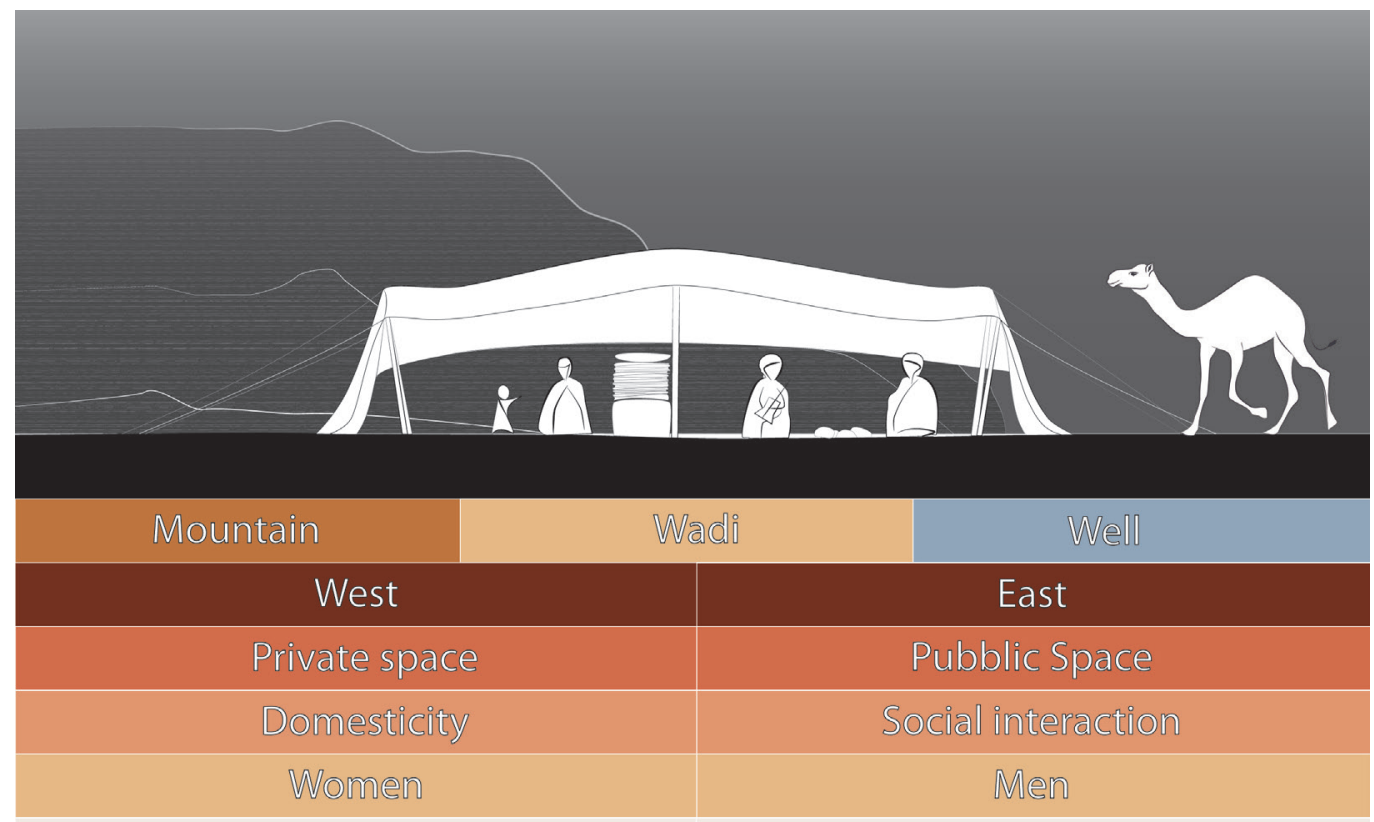

Behind the curtein

Fire Place

$\begin{array}{cc}\text { Bread making_Food preparation } & \text { Coffe preparation } \\ \text { Weaving } & \text { Welcoming guest } \\ \text { Sleeping_Bathing_Child care } & \text { Narration and Music }\end{array}$
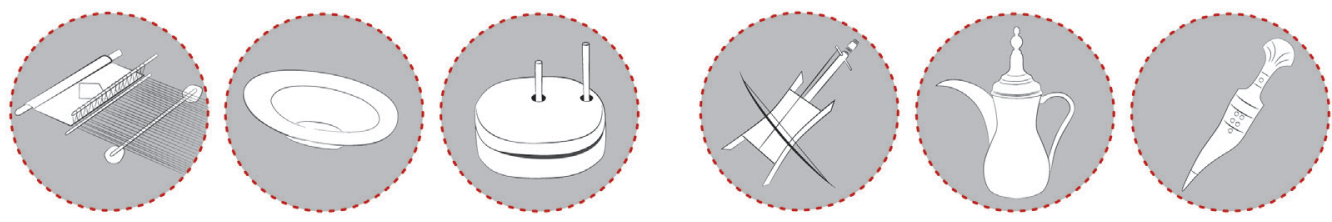
Fig. 6. Installation inspired by the black tent and the traditional Bedouin patterns for textiles and carpestry.
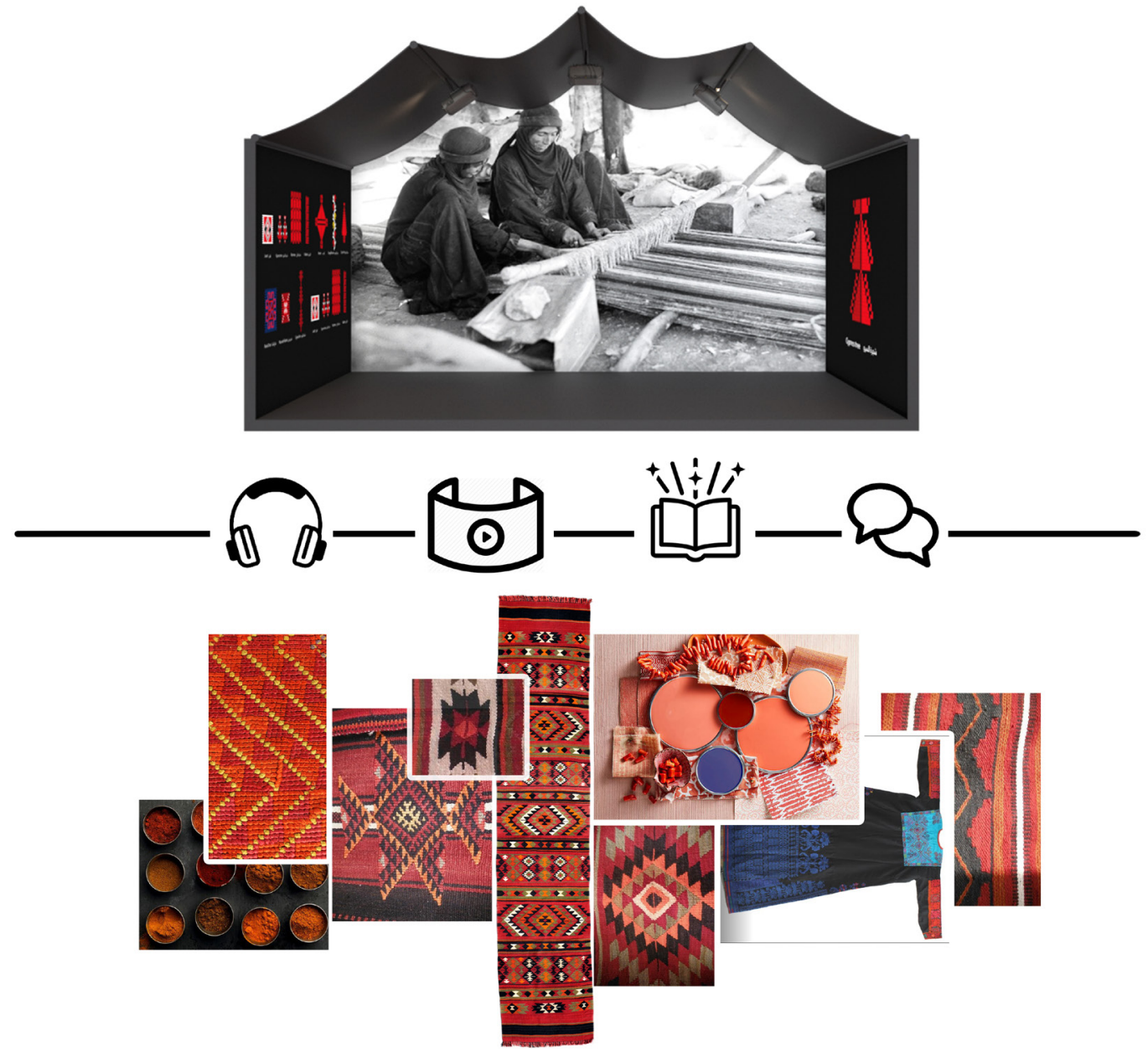

\section{Conclusions}

The research is promoting a methodological framework for the process of representing the intangible and communicating the cultural landscape linked to the Bedouin culture, to be considered as a social phenomenon, which operates on perceptual and emotional aspects, and as a cultural fact, of which to highlight those layers that justify its relevance. The process aims to amplify the role of museum institutions in the responsibility of reducing or eliminating any barriers to social inclusion. To represent a culture, so geographically rooted, it is necessary to map and identify its codes and describe with the tools of drawing the knowledge as a testimony of a living cultural tradition to entrust its custody to contemporary generations. The research proposes a methodological model of reading, interpretation and narration of the local identity by creating an articulated connection of knowledge and material expressions through the latest generation digital systems. The procedure will be tested at the Amman Roman Theater in the retrofitting of the two Jordanian museums settled there according to the international cooperation and collaborative design program. 
The typology of bedouin loom
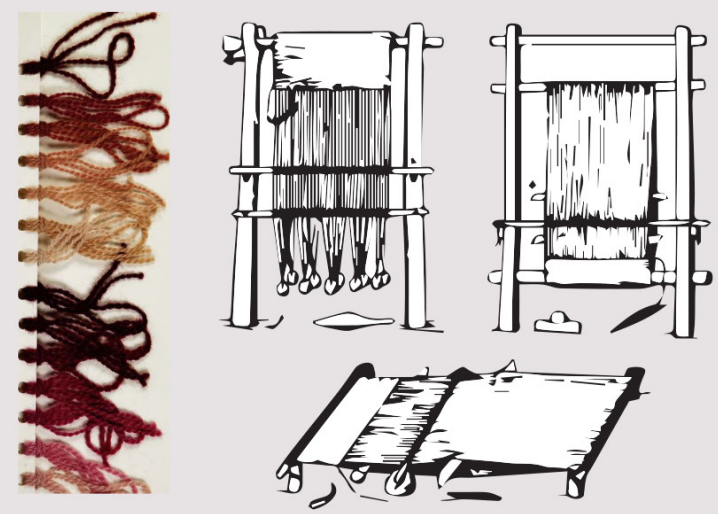

Digital library
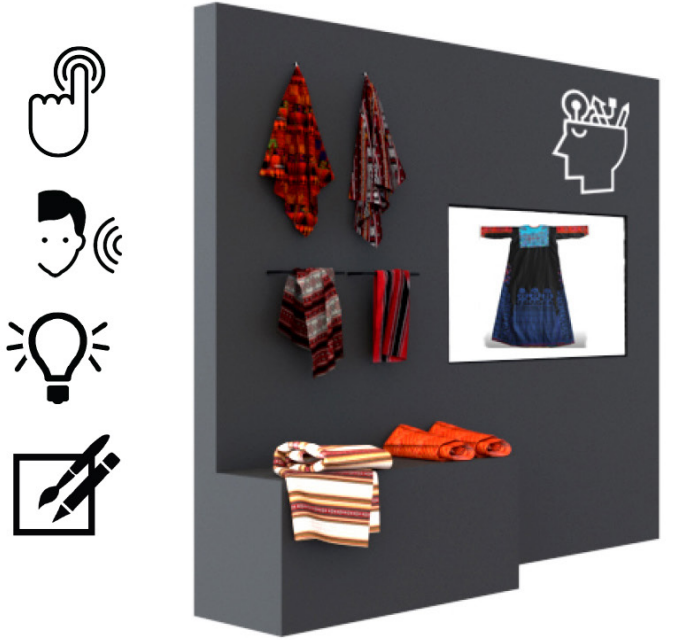

Typological pattern of bedouin textile

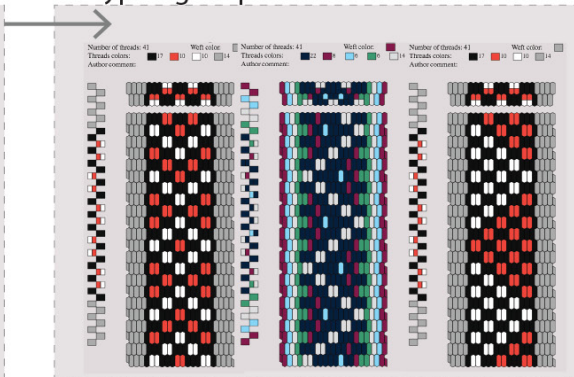

The typology of costumes
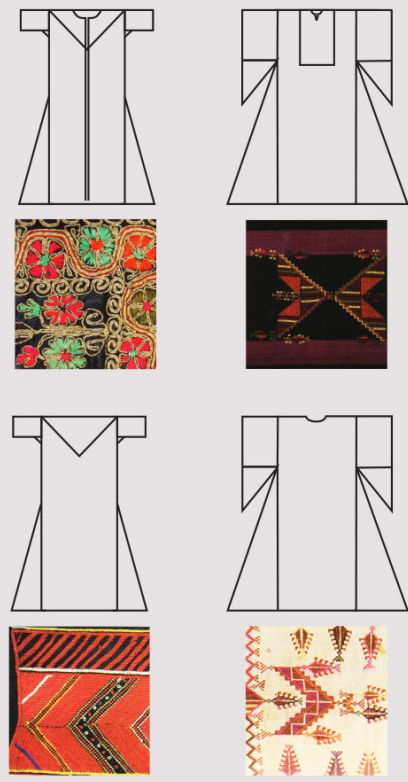

Credits

This work is part of the international research and cooperation project: Program for the definition of a strategic plan for the improvement and the enhancement of the Folklore Museum, the Museum of PopularTraditions and the site of the Roman Theater in Amman, launched in 2020. Giuseppe Amoruso is the scientific director and author of the paragraphs 'Introduction' and 'Representing the cultural landscape of the black tent as a common good'; Sara Conte developed the paragraph 'The construction system of the black tent, a nexus between habitat and folklore' and its illustrations; Polina Mironenko is the author of the 'Digital Library of Jordanian Master Craftsmen, Crafts and Traditional Arts' and its illustrations.

\section{References}

Amoruso G., Mironenko P. (2019). Heritage BIM descriptive models for the representation of resilient city. The case of Amatrice's reconstruction. In P. Belardi (a cura di). Riflessioni, L'arte del disegno/ll disegno dell'arte. Atti del $41^{\circ}$ Convegno internazionale dei Docenti delle discipline della Rappresentazione. Perugia, 19-2I settembre 20 I9. Roma: Gangemi, pp. I05 I- 056.

Amoruso G., Mironenko P. (2020). Memory as a Common Asset. Algorithmic Generative Representations for the Reconstruction of the Community Identity after the Earthquake. In A. Arena et al. (a cura di). Connettere/un disegno per annodare $e$ tessere. Atti del $42^{\circ}$ Convegno internazionale dei Docenti delle discipline della Rappresentazione, tenutosi online il 18 settembre 2020. Milano: FrancoAngeli, pp. I528- 1537.

Biasutti R. (1962). Il paesaggio terrestre. Torino: Utet.

Cappelletto C. (20I0). La natura funzionale dell'immagine nel confronto con le neuroscienze. In PsicoArt - Rivista di Arte e Psicologia, I ( I).

Convenzione di Faro. (2005). Value of cultural heritage for society. Council of Europe Framework-Convenzione quadro del Consiglio d'Europa (CETS no. 199), 18, 03-08.

Eco U. (2013). Mnemotecniche e rebus. Rimini: Guaraldi San Marino University Press. 
Erasmo V. (2020). Homo capabilitiensis: un paradigma antropologico per il futuro ispirato alla riflessione di Amartya Sen. In Alici, L., Miano, F. (a cura di) L'etica nel futuro. Roma: Orthotes Editrice pp. 455-464.

Lapiccirella Zingari V. (2015). Patrimoni vitali nel paesaggio. Note sull'immaterialità del patrimonio culturale alla luce delle Convenzioni internazionali. In L. Zagato, M.Vecco (a cura di). Citizens of Europe. Culture e diritti,Venezia: Cà Foscari Edizioni, pp. 425-456.

Marrazzo D. (28 febbraio 202 I). De Luca, l'architetto che restaura Notre Dame con 3D, digitale e videogame. In ilSole24ore. $<$ https://www.ilsole24ore.com/art/de-luca-l-architetto-che-restaura-notre-dame-3d-digitale-e-videogame-ADVsOrMB?refresh_ce $=\mid>($ accessed 6 aprile 202I).

Mironenko P. (2019). Conservation Issues on UNESCO World Heritage Sites in Russia. From the Roerich Pact to Contemporary Challenges. In Amoruso G., Salerno R. (a cura di) Cultural Landscape in Practice. Lecture Notes in Civil Engineering, vol 26. Springer, Cham.

Sacks O. (2017). Il fiume della coscienza. Milano: Adelphi.

Spangerberg,J. ( I539). Artificiosae Memoriae Libellus... Lipsiae: Impressum per Michaelem Blum.

Tarasco A.L. (2004). Beni, patrimonio e attività culturali: attori privati e autonomie territoriali. Napoli: Editoriale Scientifica.

UNESCO. (2003). Convenzione per la salvaguardia del patrimonio culturale immateriale. Trad. it. <https://ich.unesco.org/doc/ src/00009-IT-PDF.pdf> (accessed 2021, April 24)

UNESCO. (2005). Convenzione per la salvaguardia del patrimonio culturale immateriale. <https://delegazioneunesco.esteri.it/rappunesco/it/i-rapporti-bilaterali/informazioni-e-servizi/salvaguardia-patrimonio-culturale-immateriale> (accessed 2021, May I0).

UNESCO. (20l I ). Recommendation on the Historic Urban Landscape. <https://whc.unesco.org/en/hul/> (accessed 202I,April 24).

\section{Authors}

Giuseppe Amoruso, Politecnico di Milano, giuseppe.amoruso@polimi.it

Sara Conte, Politecnico di Milano, sara.conte@polimi.it

Polina Mironenko, Politecnico di Milano, polina.mironenko@polimi.it

To cite this chapter. Amoruso Giuseppe, Conte Sara, Mironenko Polina (2021). Rappresentazione dell'intangibile, cultura beduina e tecnologie per connettere/Representation of the Intangible, Bedouin Culture and Technologies to Connect. In Arena A., Arena M., Mediati D., Raffa P. (a cura di). Connettere. Un disegno per annodare e tessere. Linguaggi Distanze Tecnologie. Atti del $42^{\circ}$ Convegno Internazionale dei Docenti delle Discipline della Rappresentazione/Connecting. Drawing for weaving relationship. Languages Distances Technologies. Proceedings of the 42th International Conference of Representation Disciplines Teachers. Milano: FrancoAngeli, pp. 1902-1921. 